\title{
Sistem Pendukung Keputusan Pemilihan Mobil dengan AHP-SAW
}

\author{
Dennis Johanes Lesmana ${ }^{1}$, Seng Hansun ${ }^{2}$ \\ ${ }^{1}$ e-mail: dennis.johanes.1@gmail.com, ${ }^{2}$,hansun@umn.ac.id \\ 1,2 Program Studi Informatika, Universitas Multimedia Nusantara, Tangerang, Indonesia
}

\begin{abstract}
Car is one of the transport vehicles which is mostly used by people. Currently, there are so many types of cars in Indonesia that makes people confused when they want to buy a car. Bunch of criteria to think of when they want to buy a car makes them hard to choose. Because of that, Car Selection Decision Support System was made. Two algorithms were used to make the Car Selection Decision Support System. They are used to calculate input from user, then the user will see a ranking table based on their input. Based on the evaluation result, respondent gave a satisfied comment to this system.
\end{abstract}

Intisari- Mobil merupakan salah satu alat transportasi yang paling banyak digunakan oleh masyarakat. Saat ini, sudah banyak sekali jenis mobil di Indonesia yang menyebabkan masyarakat menjadi bingung ketika ingin membeli mobil. Banyaknya kriteria-kriteria yang dipertimbangkan dalam pembelian mobil membuat orang kesulitan dalam menentukan pilihannya. Oleh karena itu, dibuat sistem pendukung keputusan untuk memberikan rekomendasi dalam menentukan pilihan mobil yang akan dibeli. Untuk mendukung keputusan, digunakan dua algoritma yang akan menghitung input dari pengguna dan memberikan hasil berupa tabel rangking nama-nama mobil yang direkomendasikan oleh sistem. Berdasarkan hasil evaluasi, responden memberikan tanggapan puas terhadap sistem yang telah dibuat.

Kata Kunci_-SPK pemilihan mobil, Analytical Hierarchy Process, Simple Additive Weighting, Kepuasan Pengguna.

\section{PENDAHULUAN}

Terjadi kesulitan dalam pemilihan mobil oleh konsumen untuk memenuhi kebutuhan dan keinginan pribadi [1]. Perkembangan mobil setiap tahunnya terus mengalami peningkatan dengan munculnya jenis mobil baru yang menawarkan kelebihan dan kekurangan dari segi harga, isi silinder, maupun pada fitur-fitur keamanan dan kenyamanannya. Hal tersebut menyebabkan rasa kurang percaya diri bagi calon pembeli mobil terhadap pilihan mobil yang diinginkannya [2]. Oleh karena hal tersebut maka sistem untuk mendukung keputusan calon pembeli diperlukan.

Sebelum membeli mobil, sebaiknya konsumen mengetahui informasi mengenai mobil yang hendak dibeli. Pertama, konsumen harus terlebih dahulu memutuskan jenis mobil yang diinginkan. Menurut Gaikindo, jenis mobil di Indonesia dibagi menjadi berbagai kategori, yaitu sedan, mobil penggerak 4x2, mobil penggerak 4x4, kendaraan hemat bahan bakar dan harga terjangkau, pick-up atau truk, double cabin, dan bus. Terdapat tiga dampak negatif yang pada umumnya terjadi ketika manusia dihadapi dengan pilihan yang banyak, yakni penundaan pemilihan, pemilihan yang buruk, serta pemilihan yang kurang memuaskan. Salah satu cara untuk menghindari dampak tersebut adalah dengan pengembangan sistem yang mendukung proses pengambilan keputusan oleh konsumen.

Pengambilan keputusan seseorang dalam proses pemilihan mobil memerlukan pertimbangan yang cukup banyak. Konsumen dihadapkan dengan banyaknya kriteria yang berpengaruh dalam menentukan pilihan mobil, seperti harga, kenyamanan, keamanan, kapasitas penumpang, dan kapasitas mesin [3]. Oleh karena itu, aplikasi ini dibuat untuk membantu konsumen dalam memilih mobil dengan cara menampilkan hasil yang diurutkan berdasarkan nilai dari mobil yang dibandingkan.

Berdasarkan penelitian sebelumnya oleh Andy Satria Damanik pada tahun 2014, hasil pengujian sistem menghasilkan persentase 86,66\% dari user acceptance test yang disebar [2]. Aplikasi ini akan dikembangkan dengan menggunakan gabungan Simple Additive Weighting (SAW) dan Analytic Hierarchy Process (AHP) sesuai dengan saran penelitian sebelumnya untuk mendapatkan hasil alternatif yang objektif.

\section{AHP-SAW}

Sistem rekomendasi adalah teknik untuk memecahkan masalah dari banyaknya informasi atau produk berbasis computer [4]. Terdapat empat pendekatan dalam sistem rekomendasi yakni content-based filtering, collaborative filtering, hybrid-based recommendation, dan knowledge-based recommendation. Khusus content-based filtering akan didefinisikan karakteristik suatu objek yang memungkinkan sistem untuk merekomendasikan profil yang menyerupai atribut yang diinginkan oleh pengguna 
dengan mencocokkan atribut yang ada dengan tiap objek. Pendekatan tersebut digunakan dalam penelitian ini karena mencocokkan atribut dari setiap objek dengan atribut yang diinginkan oleh pengguna.

Simple Additive Weighting (SAW) membutuhkan proses normalisasi matriks keputusan (X) ke skala yang bisa dibandingkan dengan semua alternatif yang ada. Metode ini mengharuskan pembuat keputusan menentukan bobot bagi setiap atribut.

Menurut penelitian Usito [5] ada tujuh tahapan metode SAW, yaitu.

1. Menentukan alternatif-alternatif (Ai) yang ada.

2. Menentukan kriteria $(\mathrm{Cj})$ yang akan dijadikan acuan dalam pengambilan keputusan.

3. Menilai rating kecocokan setiap alternatif pada tiap kriteria.

4. Menentukan tingkatan kepentingan (W) setiap kriteria, yaitu $\mathrm{W}=[\mathrm{W} 1, \mathrm{~W} 2, \mathrm{~W} 3, \ldots, \mathrm{Wj}]$

5. Membuat tabel rating kecocokan tiap alternatif terhadap tiap kriteria yang ada.

6. Membuat matriks keputusan $(\mathrm{X})$ dari tabel rating kecocokan tiap alternatif pada tiap kriteria. Nilai X pada setiap alternatif $\left(A_{i}\right)$ pada setiap kriteria $\left(C_{j}\right)$ yang telah ditentukan, dimana, $i=1,2, \ldots, m$ dan $j=1,2, \ldots, n$.

7. Kemudian menghitung matriks keputusan ternormalisasi dari nilai rating kinerja ternormalisasi $\left(n_{i j}\right)$ alternatif $A_{i}$ pada kriteria $\mathrm{C}_{\mathrm{j}}$.

Untuk kriteria dengan nilai semakin besar semakin baik, digunakan kriteria positif yang ditunjukkan pada (1).

$$
n_{i j}=\frac{r_{i j}}{r_{i}^{\max }}
$$

Untuk kriteria dengan nilai semakin kecil semakin baik, digunakan kriteria negatif ditunjukkan pada (2).

$$
n_{i j}=\frac{r_{j}^{\min }}{r_{i j}}
$$

Hasil akhir nilai preferensi (Vi) didapat dari penjumlahan perkalian elemen baris matriks ternormalisasi (n) dengan bobot preferensi (W) yang sesuai dengan elemen kolom matriks. Ditunjukkan pada (3).

$$
V_{i}=\sum_{i=1}^{n} w_{j} n_{i j}
$$

Hasil perhitungan Vi yang lebih besar mengindikasikan bahwa alternatif Ai merupakan alternatif terbaik.

Metode AHP akan menguraikan masalah multi kriteria yang kompleks ke bentuk suatu hirarki [6, 7]. Menurut Saaty hirarki didefinisikan sebagai suatu representasi dari sebuah permasalahan yang kompleks dalam suatu struktur multi-level dimana level pertama adalah tujuan, yang diikuti level faktor, kriteria, sub kriteria, dan seterusnya hingga level terakhir dari alternatif [8].

Menurut Putri [9] tahapan dalam metode Analytic Hierarchy Process antara lain.

1. Mendefinisikan masalah, menentukan solusi, serta menyusun hierarki.

2. Menentukan bobot kriteria dengan membandingkan tiap kriteria secara berpasangan yang menghasilkan matriks perbandingan berpasangan.

3. Proses normalisasi matriks perbandingan berpasangan. Perhitungan normalisasi matriks dilakukan dengan cara (4).

$$
a_{j k}^{\prime}=\frac{a_{j k}}{\sum_{l=1}^{m} a_{l k}}
$$

Dimana

$\vec{a}_{j k}$ adalah nilai hasil normalisasi matriks perbandingan berpasangan.

$a_{\tilde{J K}}$ adalah nilai matriks perbandingan berpasangan baris ke-j kolom ke-k.

$a_{I N k}$ adalah nilai matriks perbandingan berpasangan baris ke-l kolom ke-k. 
$\mathrm{m}$ adalah batas akhir baris matriks perbandingan berpasangan.

4. Menghitung bobot sintesis dengan menjumlahkan tiap kolom pada baris yang sama dari hasil normalisasi matriks perbandingan.

5. Menghitung nilai eigen dengan mengalikan tiap kolom matriks pada baris yang sama, yang kemudian dipangkatkan dengan seperjumlah kriteria yang ada.

6. Menghitung bobot prioritas tiap kriteria dimana nilai eigen untuk tiap kriteria dibagi jumlah total nilai eigen.

7. Menghitung nilai kepentingan tiap kriteria dengan cara membagi bobot sintesis dengan bobot prioritas.

8. Menghitung nilai eigen maksimum ( $\lambda$ maks) dimana total jumlah nilai kepentingan dibagi jumlah kriteria.

9. Mengukur konsistensi dengan menghitung Consistency Index (CI, (5)) dan Consistency Ratio (CR, (6)).

$$
\begin{gathered}
C I=\frac{(\lambda m a k s-n)}{n-1} \\
C R=\frac{C I}{I R}
\end{gathered}
$$

Dimana:

CR adalah Consistency Ratio.

CI adalah Consistency Index.

IR adalah Index Random Consistency.

$\lambda$ maks adalah eigen maksimum.

$\mathrm{n}$ adalah jumlah elemen.

10. Memeriksa konsistensi hierarki rasio konsistensi (CI/IR). Bila bernilai Ñ 0,1 maka hasil dapat dinyatakan benar.

\section{RANCANGAN SISTEM}

Perancangan aplikasi menghasilkan beberapa dokumen yang menjelaskan alur aplikasi dalam bentuk flowchart, data flow diagram, hierarki menu, struktur tabel, dan rancangan antarmuka.

\section{A. Hierarki Menu}

Website memiliki empat halaman utama, yaitu halaman Home, halaman Recommendation, halaman Compare Cars, dan halaman Credits. Selain itu, ada halaman Result yang hanya bisa diakses melalui halaman Recommendation atau halaman Compare Cars. Hierarki menu disajikan dalam Gambar 1.

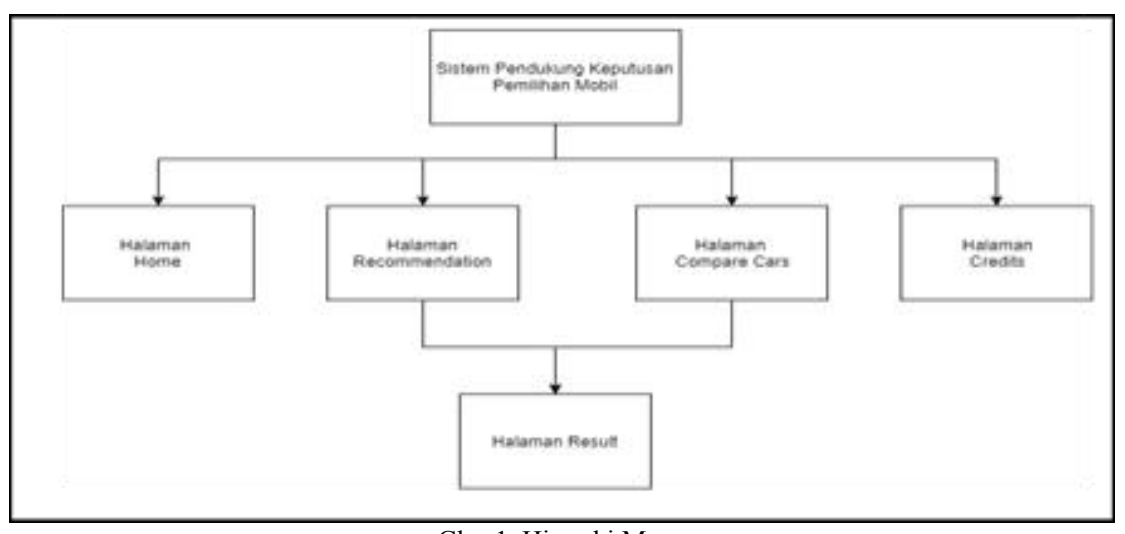

Gbr. 1. Hierarki Menu

\section{B. Data Flow Diagram}

Alur perpindahan data digambarkan dalam bentuk context diagram yang bisa dilihat pada Gambar 2. 


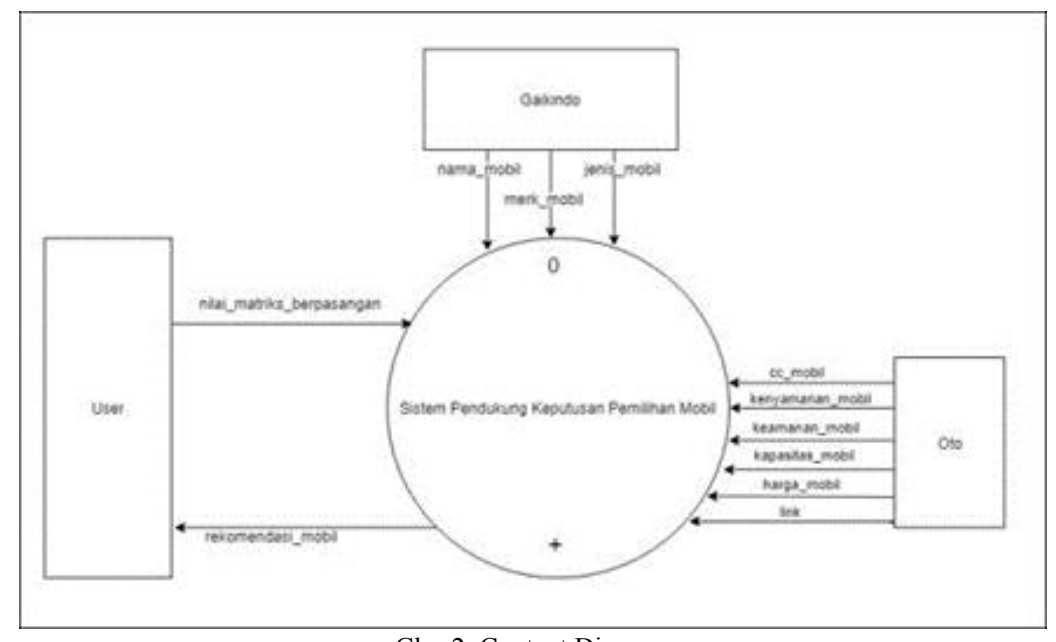

Gbr. 2. Context Diagram

Dalam context diagram ini, terdapat satu proses yaitu sistem rekomendasi pendukung keputusan mobil dan tiga entitas, yaitu user, gaikindo, dan oto. Entitas user memberikan nilai matriks berpasangan kepada sistem dan menerima rekomendasi mobil dari sistem. Gaikindo memberikan tiga data, yaitu nama mobil, merk mobil dan jenis mobil yang akan disimpan ke dalam database. Selain gaikindo, oto juga memberikan enam buah data, yaitu cc mobil, kenyamanan mobil, keamanan mobil, kapasitas mobil, harga mobil, dan link yang juga disimpan ke dalam database.

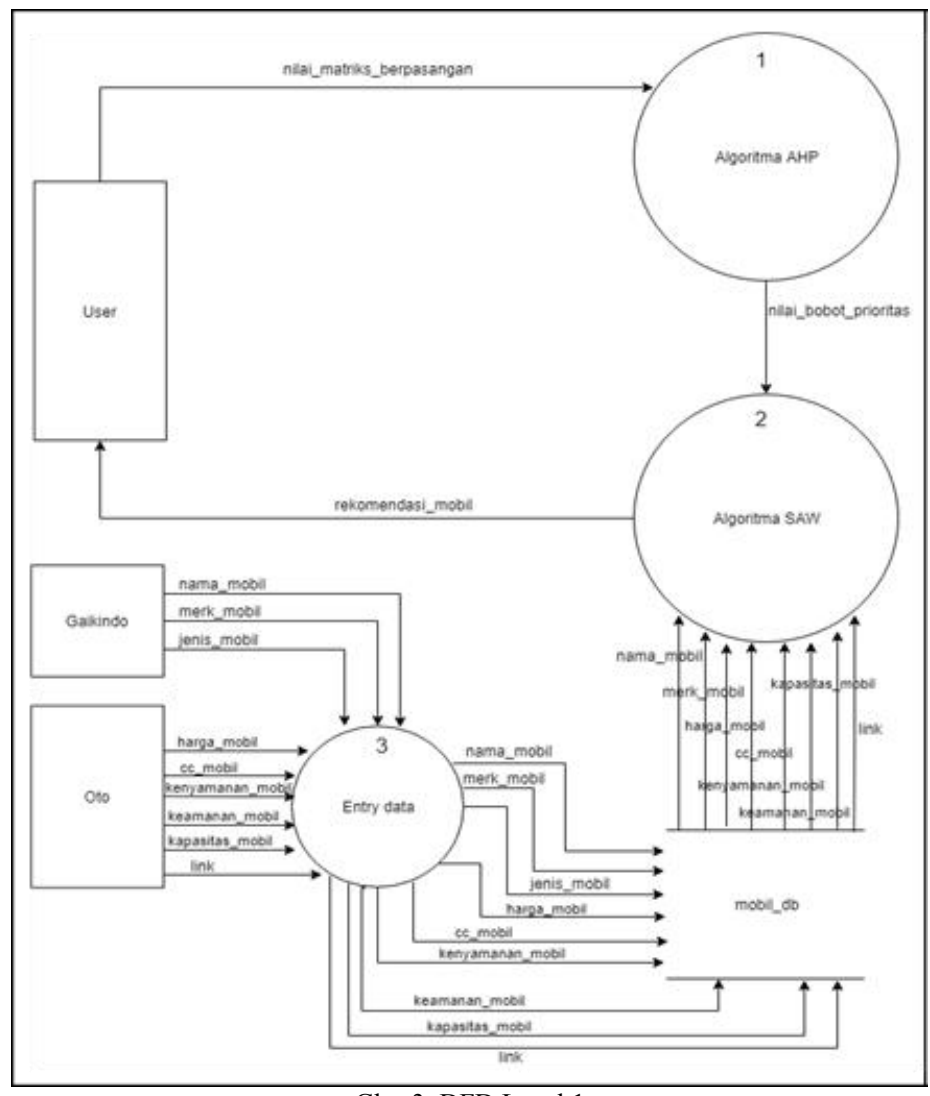

Gbr. 3. DFD Level 1

Gambar 3. menampilkan DFD Level 1 dari aplikasi. User memberikan nilai matriks berpasangan kepada algoritma AHP, setelah perhitungan AHP selesai, nilai bobot prioritas dan data dari mobil_db akan diberikan kepada algoritma SAW untuk dilakukan proses perhitungan yang menghasilkan rekomendasi mobil untuk user. Entitas Gaikindo dan Oto memberikan data untuk disimpan ke data store yang digunakan pada saat perhitungan algoritma SAW dijalankan.

\section{Flowchart}

Gambar 4 menunjukkan flowchart dari website yang akan dibuat. Pada saat website pertama kali dibuka, halaman yang pertama muncul adalah halaman Home. Selain halaman Home, juga terdapat halaman Recommendation, Compare Cars, dan 
halaman Credits. Halaman Home menampilkan penjelasan singkat mengenai website. Halaman Recommendation menampilkan tabel bobot yang akan diisi oleh user, serta panduan cara mengisinya. Halaman Compare Cars menampilkan lima select option untuk memilih mobil yang akan dibandingkan, bobot yang digunakan dalam Compare Cars tidak bisa diganti oleh user. Halaman Credits menampilkan pembuat website dan referensi yang digunakan selama pembuatan website.

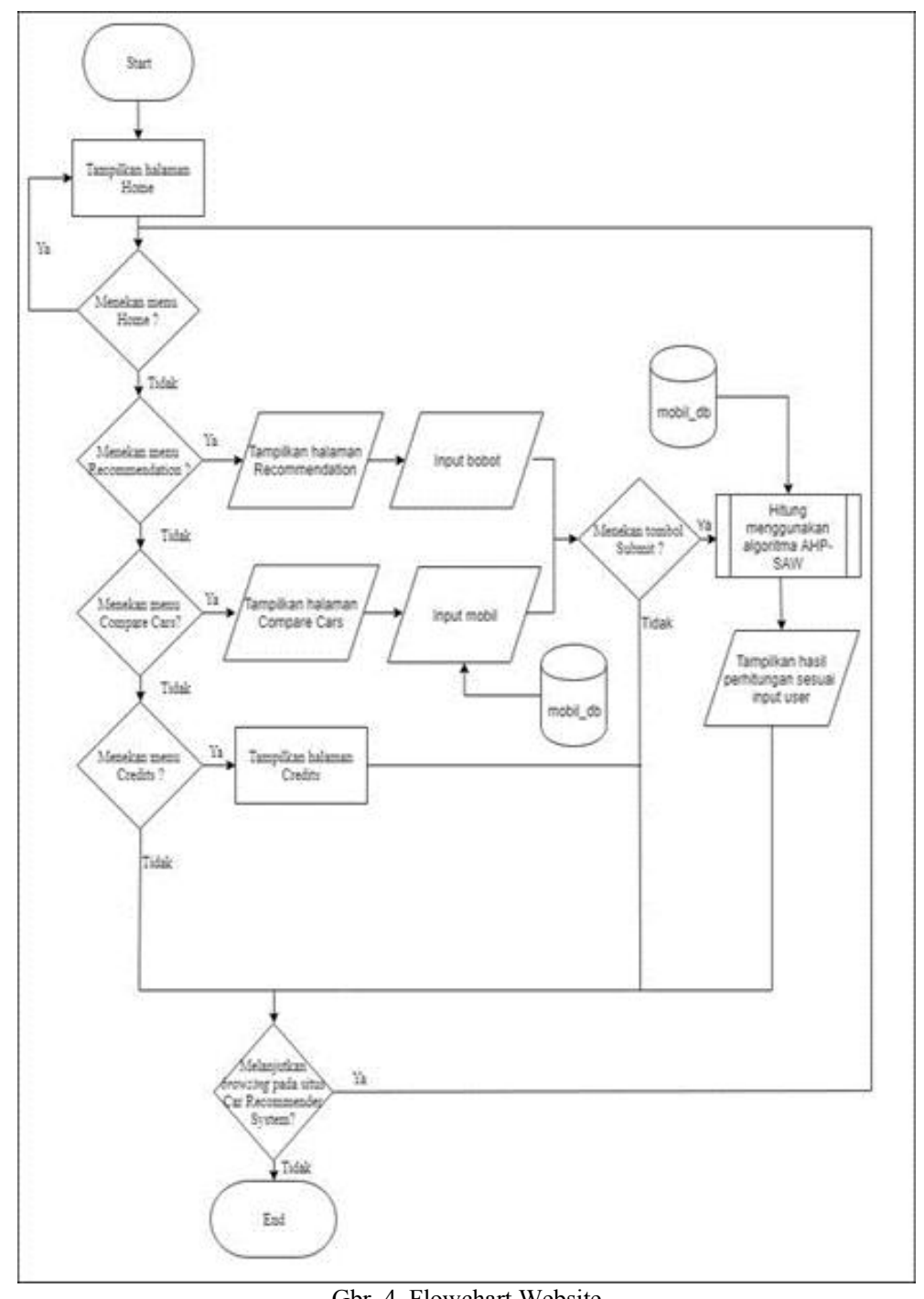

Gambar 5 menjelaskan proses algoritma AHP dan SAW yang dilakukan dalam aplikasi. Mula-mula input bobot yang dilakukan pada proses sebelumnya akan dimasukkan ke dalam matriks berpasangan. Setelah nilai matriks berpasangan dimasukkan, dilakukan penjumlahan nilai dari kriteria setiap mobil (penjumlahan per kolom). Normalisasi terhadap matriks tersebut dilakukan dengan membagi nilai tiap elemen pada matriks dengan nilai total nilai kriteria. Berikutnya nilai bobot sintetis, nilai eigen, dan nilai bobot prioritas akan dihitung. Nilai-nilai tersebut akan digunakan untuk mendapatkan nilai kepentingan kriteria dan nilai eigen maksimum yang berguna untuk menghitung nilai CI dan CR. Jika nilai CR kurang dari 0,1 maka hasil perhitungan berarti konsisten, jika tidak maka sistem akan diulang kembali dari proses memasukkan nilai bobot. Bila hasil perhitungan sudah konsisten, sistem sudah selesai melakukan perhitungan algoritma AHP dan dilanjutkan dengan algoritma SAW. Sistem akan mencari nilai maksimum untuk kriteria cc mobil, kenyamanan, keamanan, kapasitas, dan mencari nilai minimum untuk kriteria harga. Setelah nilai maksimum dan minimum didapatkan, nilai tersebut akan digunakan untuk menormalisasi data alternatif dari tabel data. Hasil normalisasi data alternatif tersebut akan dikalikan dengan nilai bobot prioritas dan dijumlahkan per baris untuk mendapatkan nilai akhir setiap mobil dan proses algoritma AHP-SAW. 


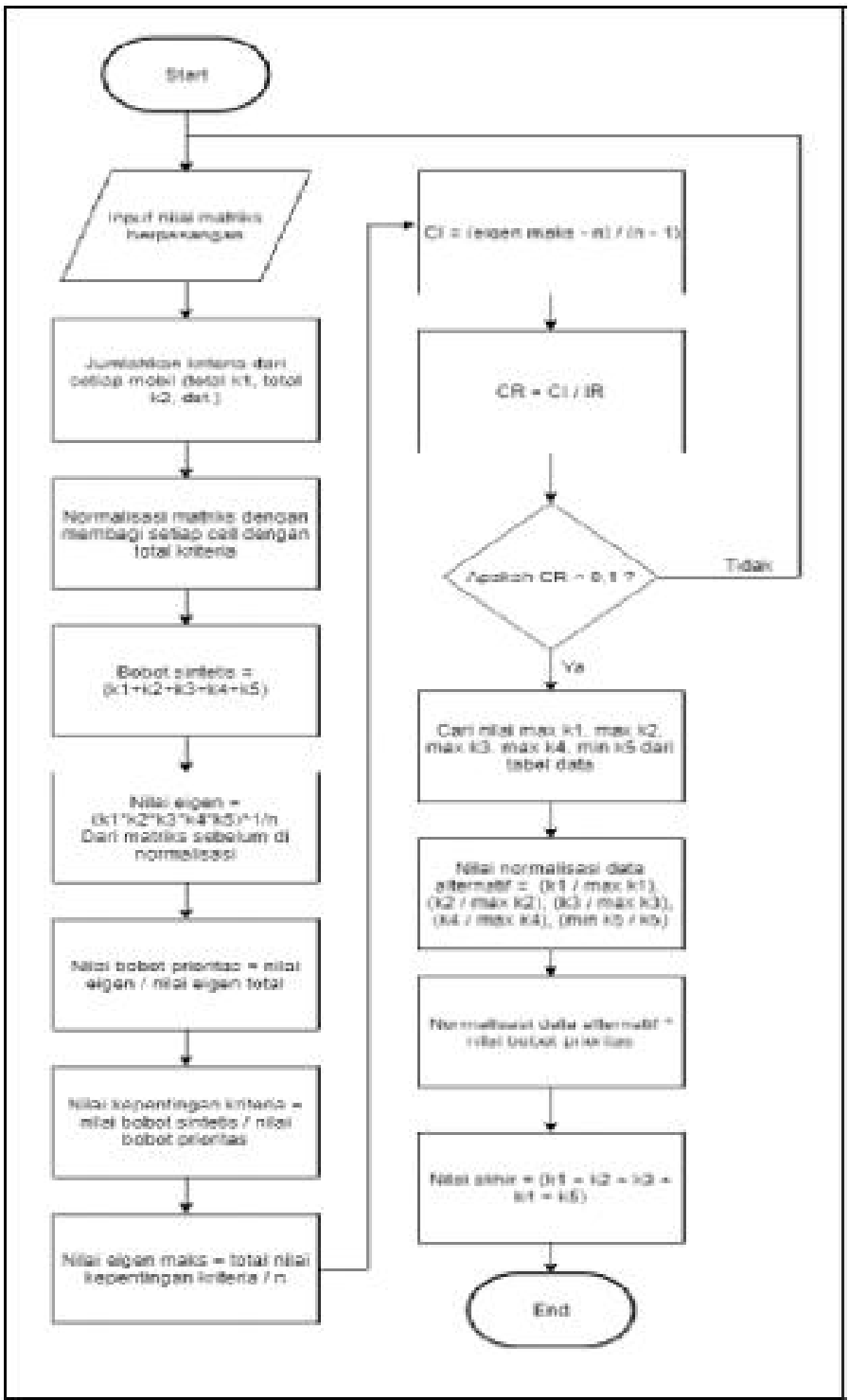

Gbr. 5. Flowchart Algoritma AHP-SAW

IV. HASIL DAN PEMBAHASAN

Pada saat website pertama kali dibuka, pengguna akan masuk ke halaman Home yang menampilkan penjelasan singkat mengenai aplikasi. Tampilan Home bisa dilihat di Gambar 6.

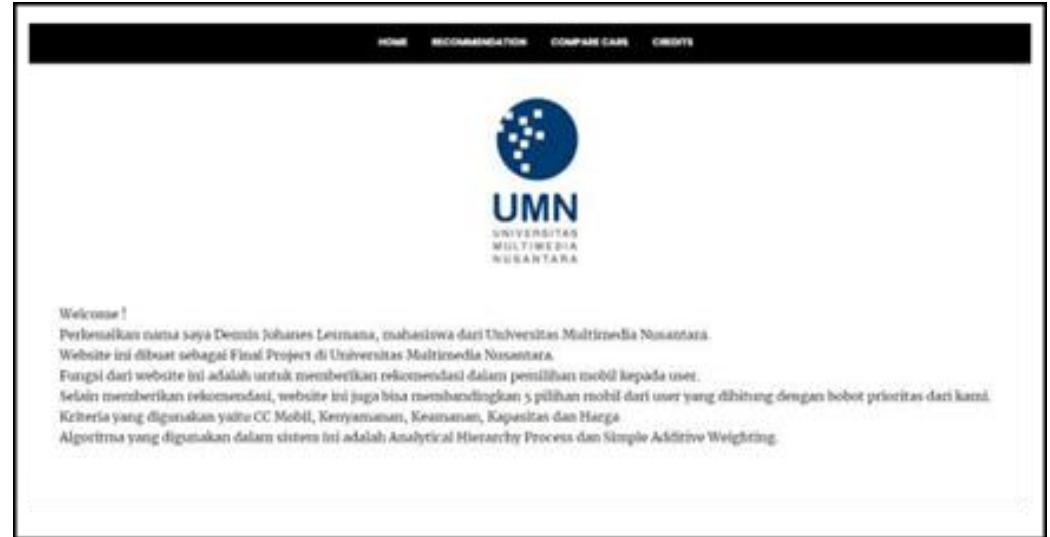

Gbr. 6. Implementasi Home 
Halaman Recommendation menampilkan penjelasan untuk mengisi tabel matriks berpasangan. Setelah tabel selesai diisi maka bisa dilakukan perhitungan algoritma dengan menekan tombol submit dan halaman akan berpindah ke halaman Result. Tampilan halaman Recommendation digambarkan pada Gambar 7.

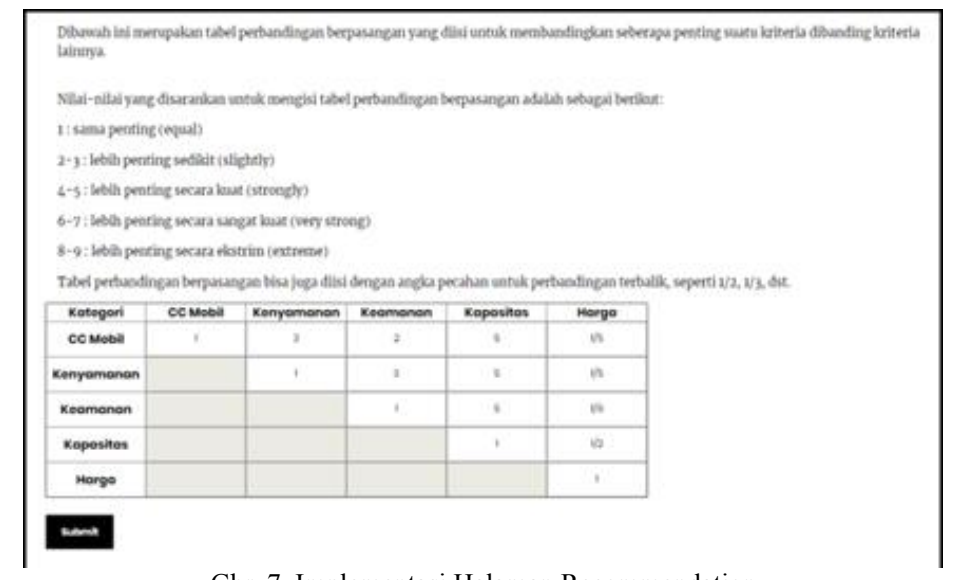

Gbr. 7. Implementasi Halaman Recommendation

Halaman Compare Cars berisi lima buah drop down list yang berisi nama-nama mobil untuk dipilih oleh user agar bisa dibandingkan dengan mobil lainnya sesuai dengan bobot yang disediakan oleh developer dengan cara menekan tombol submit. Tampilan halaman Compare Cars bisa dilihat pada Gambar 8.

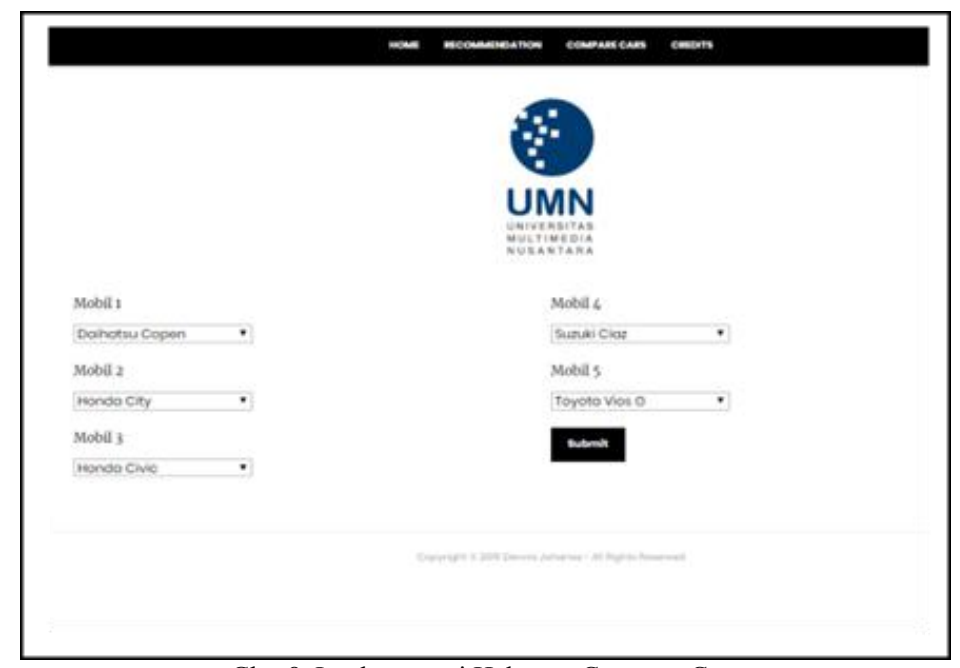

Gbr. 8. Implementasi Halaman Compare Cars

Halaman Credits menampilkan nama developer dan referensi-referensi yang paling banyak digunakan selama pembuatan sistem. Halaman Credits ditampilkan pada Gambar 9.

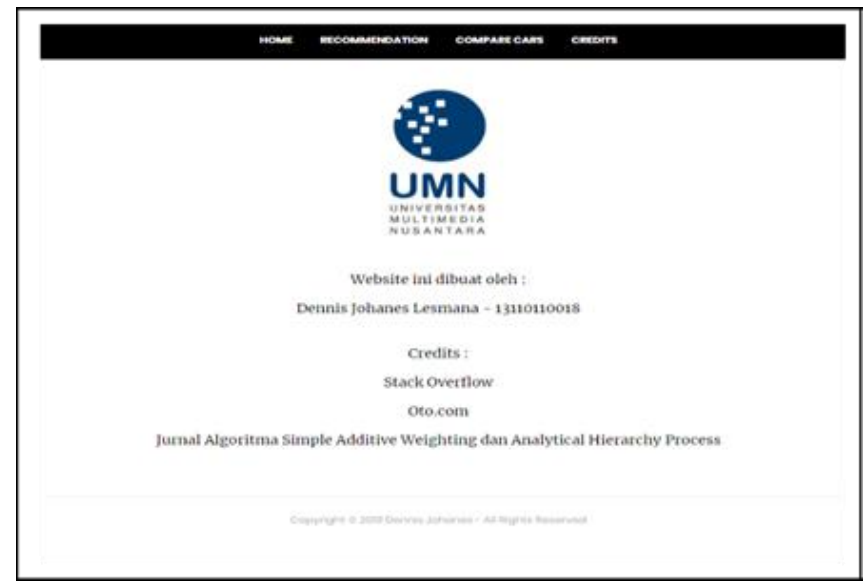


Halaman Result berisi tabel yang menampilkan penjelasan singkat dan hasil dari perangkingan sesuai dengan masukan dari pengguna pada Gambar 7. Tampilan dari halaman Result bisa dilihat pada Gambar 10.

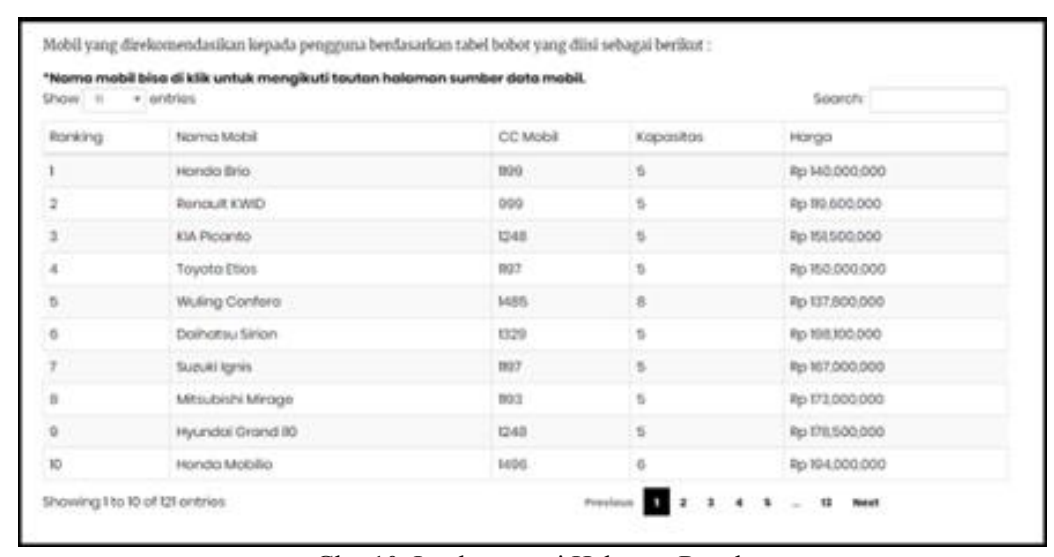

Gbr. 10. Implementasi Halaman Result

Uji coba dilakukan dengan dua jenis percobaan, uji coba algoritma dan uji coba kelayakan aplikasi. Dalam melakukan uji coba algoritma, dilakukan penelusuran manual dengan menggunakan program Microsoft Excel lalu dibandingkan dengan hasil perhitungan pada sistem. Dari pengujian algoritma yang dilakukan, hasil pada sistem dengan perhitungan manual sudah sesuai sehingga dapat dikatakan algoritma yang diimplementasikan sudah benar. Pada uji coba kelayakan aplikasi, dilakukan penyebaran kuesioner yang diisi oleh pengguna setelah mencoba aplikasi. Didapatkan 38 responden dan hasil akhir didapatkan persentase sebesar $83,7 \%$ sehingga dapat dikatakan pengguna puas terhadap sistem pendukung keputusan pemilihan mobil.

\section{KESIMPULAN}

Berdasarkan penelitian yang telah dilakukan, dapat disimpulkan bahwa sistem untuk mendukung keputusan pemilihan mobil menggunakan metode AHP dan SAW berhasil dibuat. Hasil uji coba perhitungan sistem dengan perhitungan manual menggunakan microsoft Excel sudah sama. Hasil evaluasi dengan metode field studies dan melalui kuesioner, secara keseluruhan didapatkan skor akhir $83,7 \%$ yang berarti user puas terhadap sistem yang dibuat.

\section{UCAPAN TERIMA KASIH}

Penulis mengucapkan terima kasih atas dukungan dan fasilitas yang diberikan oleh Universitas Multimedia Nusantara dalam pelaksanaan penelitian ini.

\section{REFERENSI}

[1] H. Rohayani, "Analisis Sistem Pendukung Keputusan Penentuan Pembelian Mobil Sedan Menggunakan Metode AHP," in Proceedings of Seminar Nasional Teknik Elektro (SNTE), Jakarta, Indonesia, 2013.

[2] A.S. Damanik, "Sistem Pendukung Keputusan Pemilihan Mobil Baru Menggunakan Simple Additive Weighting (SAW)," Thesis, Universitas Islam Negeri Sultan Syarif Kasim Riau, 2014.

[3] B. Arifin, "Sistem Pendukung Keputusan Rekomendasi Pemilihan Mobil Bekas dengan Menggunakan Metode Topsis," Thesis, Universitas Islam Negeri Maulana Malik Ibrahim, Malang, 2015.

[4] E. Vozalis, K.G. Margaritis, “Analysis of Recommender Systems’ Algorithms,” Universidade Federal de Pernambuco, Brazil, 2001.

[5] N.J. Usito, "Sistem Pendukung Keputusan Penilaian Proses Belajar Mengajar Menggunakan Metode Simple Additive Weighting (SAW)," Thesis, Universitas Diponegoro, Semarang, 2013.

[6] M. Lenia, S. Hansun, F.P. Putri, “An AHP-VIKOR Decision Support System for ASMA Selection,” CIENCIA e TECNICA Vitivinicola, vol.34, no.5, pp.1-12, 2019.

[7] E. Marbun, S. Hansun, "Sistem Pendukung Keputusan Pemilihan Program Studi dengan Metode SAW dan AHP," ILKOM, vol.11, no.3, pp.175-183, 2019.

[8] T.L. Saaty, The Analytic Hierarchy Process. McGraw-Hill, New York, 1980.

[9] S.R. Putri, "Sistem Pendukung Keputusan Penerimaan Pegawai Mikro Kredit Sales (MKS) Menggunakan Metode AHP dan TOPSIS," Thesis, Universitas Brawijaya, Malang, 2015. 